\title{
Effects of dietary protein source on growth, immune function, blood chemistry and disease resistance of Atlantic salmon (Salmo salar L.) parr
}

\author{
M. P. Bransden, C. G. Cartert and B. F. Nowak \\ School of Aquaculture and the Cooperative Research Centre for Aquaculture, Tasmanian Aquaculture and Fisheries \\ Institute, University of Tasmania, Launceston, Tasmania, Australia \\ † E-mail: Chris.Carter@utas.edu.au
}

\begin{abstract}
Many studies with fin fish have demonstrated the potential to use alternative dietary protein sources to fish meal based on growth responses, although these trials mostly neglect to determine if such protein sources affect immune function. This study investigated the effect of fish meal replacement with dehulled lupin meal (LPN) or hydrolysed poultry feather meal (FTH). Atlantic salmon (Salmo salar L.) parr were supplied isonitrogenous and isoenergetic diets with $40 \%$ of the dietary protein provided by LPN or FTH, or $400 \mathrm{~g} / \mathrm{kg}$ of the dietary protein provided equally by LPN and FTH (MIX). A diet mainly containing fish-meal protein acted as a control (CON). Growth, immune function, blood chemistry and disease resistance were assessed after 56 days. Significant differences $(\mathrm{P}<0 \cdot 05)$ in weight gain were detected between Atlantic salmon given the CON and FTH diets, whilst those salmon given LPN and MIX did not differ from any other. Productive protein values were significantly lower $(\mathrm{P}<0 \cdot 01)$ for salmon on FTH compared with those on CON and MIX. Immune function (as assessed by lysozyme, antiprotease, neutrophil oxygen radical production and plasma total immunoglobulin) and blood chemistry (as assessed by plasma total protein and glucose) were not significantly (P > 0.05) affected by any diet. Mortality rates of Atlantic salmon challenged with Vibrio anguillarum were not influenced by diet. These data suggest Atlantic salmon could be supplied diets with the fish meal component reduced to supply approximately $600 \mathrm{~g} / \mathrm{kg}$ of the total protein, with the remaining $400 \mathrm{~g} / \mathrm{kg}$ supplied by dehulled lupin meal or a combined dehulled lupin and hydrolysed poultry feather meal without any adverse effects on growth, immune function or blood chemistry.
\end{abstract}

Keywords: Atlantic salmon, immune response, protein intake.

\section{Introduction}

Atlantic salmon, Salmo salar L. are the most economically valuable of the salmonid family worldwide, with global production exceeding 600 000 t/year (Food and Agriculture Organization, 1997). Salmonids are carnivorous fishes, and similarly to all other species of fish so far examined, have an absolute dietary requirement for ten amino acids (National Research Council, 1993). Fish meal, which provides all of these essential amino acids (EAA) and which has a similar EAA profile to the carcass amino acid composition of salmonids including Atlantic salmon (Pike et al., 1990), is subsequently the protein of choice in salmonid diets. However, an increasing (although highly variable) cost of fish meal due to increased demand from various feed-lot sectors has resulted in the ongoing search for alternative protein sources in aquafeeds. To date, the majority of research on fish-meal replacement with alternative proteins in Atlantic salmon diets has focused on the use of proteins derived from plant sources (Anderson et al., 1992; Carter et al., 1994; Olli et al., 1995; Carter and Hauler, 2000). The use of other protein sources, such as meat and bone meals and poultry by-products from terrestrial slaughterhouses, has not been fully investigated in Atlantic salmon. However studies with other salmonids, such as rainbow trout, Oncorhynchus mykiss (Pfeffer et al., 1994; Steffens, 1994; Bureau et al., 1999 and 2000) and chinook salmon, O. tshawytscha (Fowler, 1990), have 
evaluated the potential of some of these terrestrial animal meals.

Whilst fish growth will usually be the main criteria in identifying alternative protein sources with potential for use in aquafeeds, the affect these proteins have on immune function and disease resistance should also be investigated, yet is seldom addressed. Preliminary research by Wedemeyer and Ross (1973) demonstrated rainbow trout given an isonitrogenous and isoenergetic diet differing in its protein source (maize gluten or cottonseed meal) had no effect on its susceptibly to infection from corynebacterial kidney disease. More recently however, Rumsey et al. (1994 and 1995) found that rainbow trout supplied isonitrogenous diets, but differing in their protein source (fish meal or soyabean meal) were subject to changes to their immune response. In this instance, feeding soya-bean increased serological and non-specific defense mechanisms. Growth however, was depressed in trout given the soya-bean. Krogdahl et al. (2000) also investigated the effect of immune function and disease resistance in Atlantic salmon supplied diets containing various soya-bean products. Similarly to Rumsey et al. (1994 and 1995) immune parameters including lysozyme activity and total immunoglobulin increased with the inclusion of soya bean, whilst disease resistance varied depending on the soya-bean product incorporated. Finally, Neji et al. (1993) demonstrated that rainbow trout supplied with diets with all of the protein provided by plant sources (maize gluten and soya-bean meals) were more susceptible to Aeromonas salmonicida infection compared with trout given animal protein sources (poultry by-products and blood meal). With these trials in mind, and with the understanding that aquafeed manufacturers would be hesitant to incorporate alternative protein sources that may negatively impact upon immune function (although still providing adequate growth), the present trial was undertaken. The aim was to identify partial substitutes to fish meal that promoted both growth and immune function in Atlantic salmon relative to controls given fish meal.

Proteins sources utilized in the present trial, dehulled lupin meal (Lupinus angustifolius) and hydrolysed poultry feather meal, were selected on the basis that they were domestically available, a key criteria in identifying useful alternative proteins for the Australian salmonid industry. Furthermore, both lupin (De la Higuera et al., 1988; Morales et al., 1994; Burel et al., 1998; Carter and Hauler, 2000) and feather meal (Fowler, 1990; Pfeffer et al., 1994; Steffens, 1994; Bureau et al., 2000) have shown varying degrees of success (in relation to growth) when offered as partial fish meal substitutes in salmonid diets in the past. Dehulled lupin or poultry feather meal were used to partially substitute ( $400 \mathrm{~g} /$ $\mathrm{kg}$ ) the fish-meal protein, whilst a combination of dehulled lupin and hydrolysed poultry feather meal, with each supplying $200 \mathrm{~g} / \mathrm{kg}$ of the protein, was also included. To ensure differences that may be observed could only be attributed to protein source and not protein or energy content of the whole diet, diets were formulated to be isonitrogenous and isoenergetic on a digestible basis. Growth was assessed after 56 days. Further, lysozyme activity, antiprotease activity, neutrophil oxygen radical production, and plasma concentrations of total immunoglobulin (Ig), total protein and glucose were measured to evaluate immune function and blood chemistry. Finally, a challenge against Vibrio anguillarum was used as this bacterium has the potential to cause significant mortality in Atlantic salmon populations (Roberts and Shepherd, 1997) and disease resistance trials provide the best indication of fish health in relation to diet (Waagbø, 1994).

\section{Material and methods}

Diets and growth trial

Diets were prepared to provide $380 \mathrm{~g}$ digestible crude protein per $\mathrm{kg}$ and $15.7 \mathrm{MJ}$ digestible energy per $\mathrm{kg}$ (Table 1) using ingredient in vivo digestibility values from a previous trial with Atlantic salmon (C. G. Carter et al., unpublished results). A control $(\mathrm{CON})$ diet was formulated with fish meal supplying proportionately over 0.95 of the dietary protein. Dehulled lupin (Lupinus angustifolius, LPN) and hydrolysed poultry feather meal (FTH) were selected as alternative protein sources, and incorporated into diets to the extent that their protein replaced $400 \mathrm{~g} /$ $\mathrm{kg}$ of the fish-meal protein. A fourth diet was formulated whereby $400 \mathrm{~g} / \mathrm{kg}$ of the fish-meal protein was replaced with $200 \mathrm{~g} / \mathrm{kg}$ protein from the dehulled lupin meal, and $200 \mathrm{~g} / \mathrm{kg}$ protein from the hydrolysed poultry feather meal (MIX). Diets were pelleted through a cold pellet press (CL-2 laboratory pellet mill, California Pellet Mill Co., San Francisco, USA).

Growth trials were conducted at the School of Aquaculture, University of Tasmania (Australia). The fresh water semi-recirculation system consisted of twelve $300 \mathrm{l}$ circular tanks. A constant supply of fresh water meant a proportional exchange rate of about 0.15 per day with recirculating water treated through physical and bio-filters. Water temperature was maintained at $15 \pm 1^{\circ} \mathrm{C}$, whilst photoperiod was natural (approx. $10 \mathrm{~h}$ light: $14 \mathrm{~h}$ dark). Dissolved oxygen, ammonia, nitrate, nitrite and $\mathrm{pH}$ were 
Table 1 Formulation and determined chemical composition of the experimental diets

\begin{tabular}{|c|c|c|c|c|}
\hline & \multicolumn{4}{|c|}{ Diet } \\
\hline & $\mathrm{CON}$ & LPN & FTH & MIX \\
\hline \multicolumn{5}{|l|}{ Ingredient composition $(\mathrm{g} / \mathrm{kg})$} \\
\hline Fish meal & $591 \cdot 0$ & $331 \cdot 5$ & $331 \cdot 5$ & $331 \cdot 0$ \\
\hline Poultry feather meal & 0.0 & 0.0 & $229 \cdot 0$ & $114 \cdot 6$ \\
\hline Lupin (dehulled) & $0 \cdot 0$ & $443 \cdot 0$ & $0 \cdot 0$ & $222 \cdot 0$ \\
\hline Wheat flour & $100 \cdot 0$ & $100 \cdot 0$ & $100 \cdot 0$ & $100 \cdot 0$ \\
\hline Wheat gluten & $40 \cdot 0$ & $40 \cdot 0$ & $40 \cdot 0$ & $40 \cdot 0$ \\
\hline Vitamin and mineral pre-mixt & $3 \cdot 0$ & $3 \cdot 0$ & $3 \cdot 0$ & $3 \cdot 0$ \\
\hline Stay-C 35\% & $0 \cdot 2$ & 0.2 & $0 \cdot 2$ & $0 \cdot 2$ \\
\hline Fish oil & $87 \cdot 0$ & $82 \cdot 2$ & $113 \cdot 7$ & $98 \cdot 0$ \\
\hline Dextrose & $50 \cdot 0$ & $0 \cdot 0$ & $74 \cdot 0$ & $0 \cdot 0$ \\
\hline Diatomaceous earth & $58 \cdot 8$ & 0.0 & $38 \cdot 6$ & $21 \cdot 2$ \\
\hline Bentonite & $70 \cdot 0$ & $0 \cdot 1$ & $70 \cdot 0$ & $70 \cdot 0$ \\
\hline \multicolumn{5}{|l|}{ Chemical composition (g/kg DM) } \\
\hline Dry matter $(\mathrm{DM})(\mathrm{g} / \mathrm{kg})$ & $950 \cdot 9$ & $957 \cdot 3$ & $960 \cdot 7$ & $962 \cdot 6$ \\
\hline Crude protein $(\mathrm{CP})$ & $442 \cdot 8$ & $428 \cdot 8$ & $438 \cdot 2$ & $436 \cdot 4$ \\
\hline Crude fat & $171 \cdot 8$ & 169.9 & $184 \cdot 7$ & $183 \cdot 5$ \\
\hline Ash & $205 \cdot 2$ & 59.4 & $152 \cdot 5$ & $137 \cdot 6$ \\
\hline Gross energy (MJ/kg DM) & $18 \cdot 6$ & $20 \cdot 8$ & $20 \cdot 0$ & 19.9 \\
\hline Digestible CP & $389 \cdot 0$ & $377 \cdot 1$ & $377 \cdot 1$ & $377 \cdot 1$ \\
\hline Digestible energy (MJ /kg DM) & $15 \cdot 7$ & $15 \cdot 7$ & $15 \cdot 7$ & $15 \cdot 7$ \\
\hline Digestible CP : digestible energy (g CP per $\mathrm{MJ}$ ) & $24 \cdot 8$ & $24 \cdot 1$ & $24 \cdot 1$ & $24 \cdot 1$ \\
\hline
\end{tabular}

+ Supplied to exceed dietary requirements for salmonids (NRC, 1993)

monitored and remained within limits recommended for Atlantic salmon (Wedemeyer, 1996).

Atlantic salmon parr (mean body weight $35.9 \mathrm{~g}$ ) were randomly allocated between each of the 12 tanks until a total of 25 fish were in each tank. A further five fish were euthanased with a lethal concentration of benzocaine (ethyl-p-aminobenzoate, Sigma Aldrich, Castle Hill, NSW, Australia, $100 \mathrm{mg} / \mathrm{l}$ ) and frozen $\left(-20^{\circ} \mathrm{C}\right)$ for initial carcass chemical composition. Triplicate tanks of fish were fed by hand one of the four diets once per day (09:00 h). Based on earlier comparable studies, a daily ration of $1.25 \%$ of tank biomass was used to ensure all food would be consumed, and to avoid differences in food intake often associated with satiation feeding of plant substituted diets (De la Higuera et al., 1988; Refstie et al., 1998). Fish were weighed after being anaesthetized (benzocaine, $30 \mathrm{mg} / \mathrm{l}$ ) at 14-day intervals following a starvation period of $36 \mathrm{~h}$. The growth trial was conducted for a total of 56 days, at which time all fish were removed and weighed.

\section{Sample collection and analysis}

At the end of the growth trial, after final weighing, five fish per tank were euthanased (benzocaine, $100 \mathrm{mg} / \mathrm{l}$ ) and bled via the caudal vein using heparinized syringes and needles for measurement of immune function and blood chemistry. Whole blood was used for the measurement of neutrophil activity by the reduction of nitroblue tetrazolium (NBT) to formazan, with values presented as the optical density at $540 \mathrm{~nm}$ after reduction (Anderson and Siwicki, 1996) Remaining blood was centrifuged $(1000 \times \mathrm{g}, 5 \mathrm{~min})$ to reveal plasma. Plasma was used for measurement of lysozyme activity by determining the rate of lysis of a Micrococcus lysodeikticus suspension and using hen egg white lysozyme (Sigma Chemical Co., Castle Hill, NSW, Australia) as standard as described by Thompson et al. (1994). The volume of plasma required to inhibit $50 \%$ of a standard trypsin activity was used to quantify antiprotease activity (Ellis, 1990). The difference in plasma protein concentration (measured according to Lowry et al. (1951)) before and after precipitation with polyethylene glycol was considered to be the plasma immunoglobulin fraction (Siwicki et al., 1994). Finally, plasma glucose was measured using a commercial diagnostic kit (Sigma Chemical Co., Castle Hill, NSW, Australia). A further three fish per tank were euthanased, frozen ($20^{\circ} \mathrm{C}$ ) and kept for final carcass chemical composition. Diets and carcasses were analysed for dry matter, crude protein (Association of Official Analytical Chemists (AOAC), 1990) using a conversion factor of $\mathrm{N} \times 5.85$ (Gnaiger and Bitterlich, 
1984), crude fat (Bligh and Dyer, 1959) and ash (AOAC, 1995). Gross energy of diets was measured by bomb calorimetry.

\section{Disease resistance trial}

Eleven Atlantic salmon from each of the growth trial tanks were stocked into one of twelve 1201 rectangular fiberglass tanks supplied with flowthrough fresh water. The tanks were housed in an insulated room with controlled photoperiod $(10 \mathrm{~h}$ light: $14 \mathrm{~h}$ dark) but under ambient temperature (range $10-14^{\circ} \mathrm{C}$ ). Salmon were allowed to acclimatize for 3 days before the challenge commenced. The challenge bacterium, Vibrio anguillarum (serovar O1) was passaged through several Atlantic salmon prior to the disease resistance experiment to increase pathogen virulence. Twenty-four hours before $V$. anguillarum was administered, a fresh culture of the passaged bacterium was prepared (Oxoid Nutrient Broth no. 2, Oxoid Ltd, Basingstoke, England, plus $10 \% \mathrm{NaCl}$ ). On the day of the challenge, the culture was washed in sterile phosphate buffered saline (PBS, pH 7.2) with intermediate centrifugation (3000 $\times \mathbf{g}, 10 \mathrm{~min})$. Cells were then counted in a haemocytometer under phase contrast microscopy and adjusted (with PBS) to $3 \times 10^{5}$ cells per ml. Cell densities were confirmed by serially diluting the culture and distributing suspensions onto dry horse blood agar plates (Tasmanian Laboratory Services, Launceston, Australia) using a calibrated pipette. Colonies were then counted after $48 \mathrm{~h}$. One-hundred $\mu \mathrm{l}$ of the $3 \times 10^{5}$ cells $/ \mathrm{ml}$ suspension was injected into the intraperitoneal cavity of each Atlantic salmon after they had been anaesthetized (benzocaine, $30 \mathrm{mg} / \mathrm{l}$ ). Tanks were assessed for mortalities at 17:00 $\mathrm{h}$ on each day post injection, with death by the challenge organism confirmed by culturing kidney swabs (after sterile dissection) on blood agar and checking colonial morphology. The challenge was terminated after 14 days at which time mortalities had ceased.

\section{Statistical analysis}

Significant differences were determined by performing one way analysis of variance (ANOVA) followed by a Tukey-Kramer multiple comparison of means. Statistical significance was accepted at a probability value of 0.05 or less. Data from the growth trial was analysed using the mean value from a tank as the experimental unit, whilst individual fish were used as the experimental unit (as is the accepted convention in fish immunology and related studies (Jarp and Tverdal, 1997)) for analysis of nonspecific and specific immune function and blood chemistry. Mortality rates during challenges were compared using the log-rank test (Peto et al., 1977). Statistical analyses were performed using J. M. P. version 3. $2 \cdot 1$ (Statistical Analysis Systems Institute Inc.). Data are presented as the means of each group and standard error together with the significance levels of the main effects.

\section{Results}

Growth and carcass chemical composition

After 56 days, groups of Atlantic salmon given the CON diet had significantly $(P<0.05)$ elevated weight gain compared with those given the FTH diet, whilst weight gain of salmon on LPN and MIX were intermediate and not different from those on any other diet (Table 2). Productive protein value (PPV) differed between diets, with those salmon on the CON and MIX diets having significantly $(P<0 \cdot 01)$ greater PPVs than those given the FTH diet, whilst

Table 2 Effect of experimental diets on growth, food efficiency, productive protein value and survival of Atlantic salmon parr (means of three replicates)

\begin{tabular}{|c|c|c|c|c|c|c|}
\hline & & \multicolumn{4}{|c|}{ Diet } & \multirow[t]{2}{*}{ Significance } \\
\hline & & $\mathrm{CON}$ & LPN & FTH & MIX & \\
\hline \multirow[t]{2}{*}{ Final wet weight $(\mathrm{g})$} & Mean & $71 \cdot 0^{\mathrm{a}}$ & $67 \cdot 4^{\mathrm{ab}}$ & $67 \cdot 1^{\mathrm{b}}$ & $67 \cdot 9^{\mathrm{ab}}$ & * \\
\hline & s.e. & $1 \cdot 2$ & $0 \cdot 3$ & $1 \cdot 0$ & $0 \cdot 2$ & \\
\hline \multirow[t]{2}{*}{ Weight gain (g) } & Mean & $34.9^{\mathrm{a}}$ & $31 \cdot 7^{\mathrm{ab}}$ & $30 \cdot 8^{\mathrm{b}}$ & $32 \cdot 2^{\mathrm{ab}}$ & $*$ \\
\hline & s.e. & $1 \cdot 1$ & $0 \cdot 2$ & 0.7 & 0.5 & \\
\hline \multirow[t]{2}{*}{ FER $(g / g$ DM $) \dagger$} & Mean & $1 \cdot 13$ & 1.07 & 1.07 & $1 \cdot 10$ & \\
\hline & s.e. & 0.02 & 0.00 & 0.01 & 0.02 & \\
\hline \multirow[t]{2}{*}{ PPV (\%)‡ } & Mean & $39 \cdot 5^{\mathrm{a}}$ & $36 \cdot 9^{\mathrm{ab}}$ & $34 \cdot 4^{\mathrm{b}}$ & $37 \cdot 8^{a}$ & $* *$ \\
\hline & s.e. & $1 \cdot 0$ & 0.5 & 0.3 & 0.7 & \\
\hline \multirow[t]{2}{*}{ Survival (\%)§ } & Mean & $100 \cdot 0$ & $100 \cdot 0$ & $98 \cdot 6$ & $100 \cdot 0$ & \\
\hline & s.e. & 0.0 & 0.0 & 1.3 & 0.0 & \\
\hline
\end{tabular}

a,b Mean values across each row not sharing a common superscript were significantly different $(P<0 \cdot 005)$.

† FER, food efficiency ratio = total weight gain $(\mathrm{g}) /$ total food consumption (g dry matter).

$\ddagger$ PPV, productive protein value $=100 \times[$ fish protein gain $(\mathrm{g} \mathrm{CP}) /$ total protein consumption $(\mathrm{g} \mathrm{CP})]$.

$\S$ Percentage survival from growth trial. 
Table 3 Effect of experimental diets on carcass chemical composition of Atlantic salmon parr (means of three replicates)t

\begin{tabular}{|c|c|c|c|c|c|c|}
\hline & & \multicolumn{4}{|c|}{ Diet } & \multirow[t]{2}{*}{ Significance } \\
\hline & & $\mathrm{CON}$ & LPN & FTH & MIX & \\
\hline \multirow[t]{2}{*}{ Dry matter (g/kg) } & Mean & $292 \cdot 7$ & $293 \cdot 6$ & $296 \cdot 2$ & 293.5 & \\
\hline & s.e. & $3 \cdot 0$ & $1 \cdot 3$ & 0.7 & 0.3 & \\
\hline \multirow[t]{2}{*}{ Crude protein (g/kg WW) } & Mean & $158 \cdot 6^{\mathrm{a}}$ & $156 \cdot 0^{\mathrm{a}}$ & $152 \cdot 5^{\mathrm{b}}$ & $156 \cdot 4^{\mathrm{a}}$ & $* *$ \\
\hline & s.e. & $0 \cdot 4$ & 0.9 & 0.8 & $0 \cdot 1$ & \\
\hline \multirow[t]{2}{*}{ Total lipid (g/kg WW) } & Mean & $104 \cdot 2$ & $105 \cdot 7$ & $113 \cdot 3$ & $105 \cdot 5$ & \\
\hline & s.e. & $3 \cdot 1$ & $1 \cdot 8$ & $3 \cdot 1$ & $0 \cdot 6$ & \\
\hline \multirow[t]{2}{*}{ Ash (g/kg WW) } & Mean & $22 \cdot 1^{\mathrm{a}}$ & $22 \cdot 3^{a}$ & $20 \cdot 9^{\mathrm{b}}$ & $21 \cdot 7^{\mathrm{ab}}$ & * \\
\hline & s.e. & $0 \cdot 1$ & $0 \cdot 4$ & $0 \cdot 1$ & $0 \cdot 3$ & \\
\hline
\end{tabular}

a,b Mean values across each row not sharing a common superscript were significantly different.

+ Carcass chemical composition $(\mathrm{g} / \mathrm{kg}$ wet weight $(\mathrm{WW})$ ) of initial group (mean \pm s.e., no. $=5$ ): dry matter, $283.3 \pm 1.7 \mathrm{~g} / \mathrm{kg}$; crude protein, $162 \cdot 4 \pm 0 \cdot 5$; total lipid, $93 \cdot 2 \pm 2 \cdot 1 ;$ ash, $21 \cdot 6 \pm 0 \cdot 2$.

salmon on the LPN diet were intermediate. During the growth trial, survival was not influenced by diet with all groups having equal or very close to $100 \%$.

Dietary treatment had a significant effect on carcass crude protein and ash, though there were no differences in dry matter or total lipid content (Table $3)$. Carcass crude protein was significantly $(P<0.01)$ reduced in salmon given FTH compared with those on all other diets. Ash content was highest in salmon given LPN and CON which was significantly greater $(P<0.05)$ than their counterparts on FTH, whilst salmon on MIX did not differ from those on any other diet.

Immune function, blood chemistry and disease resistance No significant differences $(P>0 \cdot 05)$ in lysozyme activity, antiprotease activity, neutrophil oxygen radical production, or plasma concentrations of total Ig, total protein or glucose were recorded between dietary treatments (Table 4).
Mortalities from $V$. anguillarum-challenged Atlantic salmon first occurred on day 6 post-challenge in all groups excluding those given the CON diet (Figure 1). Mortalities ceased firstly in the salmon on LPN after day 9, whilst the final mortalities occurred for the salmon on CON and MIX on day 11. At this time, cumulative mortality rates of salmon on LPN and FTH were approximately $16 \%$, whilst salmon on MIX and CON had mortality rates of approximately $22 \%$. Analysis by the log-rank test revealed no significant difference in mortality rates.

\section{Discussion}

Growth and efficiencies

Despite growth rates of Atlantic salmon given the CON diet out-performing those given the remaining fish-meal-substituted diets, a lack of any statistical significance (at $P=0.05$ probability) demonstrated dehulled lupin or a combination of dehulled lupin and poultry feather meal could be incorporated into

Table 4 Effect of experimental diets on immune function and blood chemistry of Atlantic salmon parr (means of 15 replicates) (no significant differences $(P>0.05)$ were recorded $)$

\begin{tabular}{|c|c|c|c|c|c|}
\hline & & \multicolumn{4}{|c|}{ Diet } \\
\hline & & $\mathrm{CON}$ & LPN & FTH & MIX \\
\hline \multirow[t]{2}{*}{ Lysozyme $(\mu \mathrm{g} / \mathrm{ml})$} & Mean & $4 \cdot 61$ & $3 \cdot 27$ & $3 \cdot 86$ & $4 \cdot 88$ \\
\hline & s.e. & $0 \cdot 48$ & $0 \cdot 34$ & $0 \cdot 43$ & $0 \cdot 68$ \\
\hline \multirow[t]{2}{*}{ Antiprotease ( $\mu$ l plasma for $50 \%$ inhibition) } & Mean & 0.50 & $0 \cdot 43$ & 0.52 & 0.53 \\
\hline & s.e. & $0 \cdot 04$ & $0 \cdot 03$ & 0.04 & $0 \cdot 05$ \\
\hline \multirow{2}{*}{ Neutrophil (OD) } & Mean & $0 \cdot 197$ & $0 \cdot 196$ & $0 \cdot 203$ & $0 \cdot 208$ \\
\hline & s.e. & 0.009 & $0 \cdot 012$ & $0 \cdot 015$ & $0 \cdot 015$ \\
\hline \multirow{2}{*}{ Total immunoglobulin (mg/ml) } & Mean & $20 \cdot 5$ & $14 \cdot 6$ & $19 \cdot 2$ & $17 \cdot 1$ \\
\hline & s.e. & $5 \cdot 0$ & $2 \cdot 2$ & 3.9 & $4 \cdot 3$ \\
\hline \multirow[t]{2}{*}{ Total protein $(\mathrm{mg} / \mathrm{ml})$} & Mean & $40 \cdot 3$ & 38.5 & 39.4 & $40 \cdot 5$ \\
\hline & s.e. & 0.6 & 0.5 & 0.5 & $1 \cdot 0$ \\
\hline \multirow{2}{*}{ Glucose $(\mathrm{mmol} / \mathrm{l})$} & Mean & $3 \cdot 10$ & 3.38 & 3.52 & $3 \cdot 40$ \\
\hline & s.e. & $0 \cdot 10$ & $0 \cdot 18$ & $0 \cdot 22$ & $0 \cdot 18$ \\
\hline
\end{tabular}




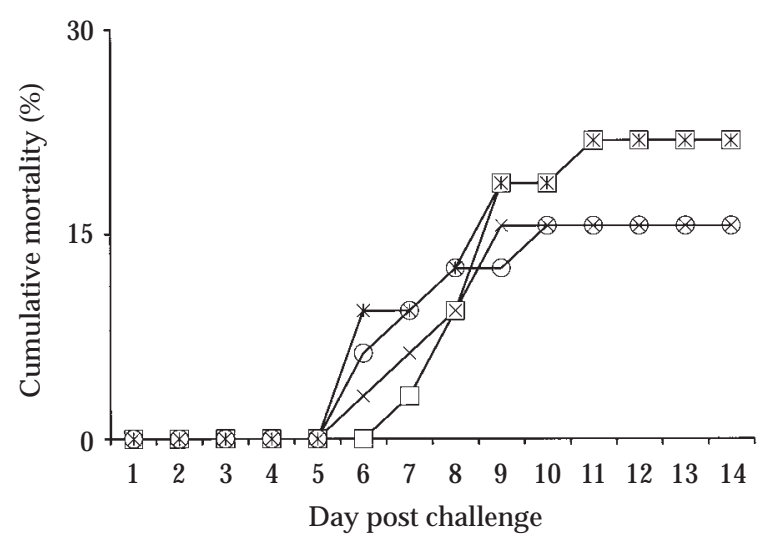

Figure 1 Cumulative mortality (\%) observed in Atlantic salmon given the CON $(\square)$, LPN $(\times)$, FTH $(\bigcirc)$ or MIX (*) diets for 56 days and then challenged with Vibrio anguillarum (serovar O1). No significant differences $(P>0.05)$ were recorded by log rank analysis.

Atlantic salmon diets, whilst poultry feather meal alone appears inadequate as a replacement for fish meal at $400 \mathrm{~g} / \mathrm{kg}$ of the protein. PPVs were found not to differ for the LPN and MIX diets relative to the CON diet and suggested lupin or the combined lupin and poultry feather meal satisfactorily promoted protein growth. PPV of approximately $40 \%$ for the control diet is in close agreement with other closely related studies on salmonids where fish meal is the principal dietary protein (Rumsey et al., 1993; Perera et al., 1995; Carter and Hauler, 2000), whilst protein productivity in the salmon on LPN was proportionately about 0.1 higher (De la Higuera et al., 1988; Carter and Hauler, 2000) or lower (Carter and Hauler, 1998) when lupin meal was supplied to other salmonids at 300 to $400 \mathrm{~g} / \mathrm{kg}$ of the dietary protein. Given that all diets were balanced for digestible crude protein and energy, the significant reduction in PPV in the salmon given the FTH diet suggested the protein quality in the poultry feather meal was insufficient relative to the control. A similar reduction in protein productivity has been recorded in rainbow trout when half or more of the fish-meal protein was replaced with combined poultry by-product and poultry feather meal (Steffens, 1994), with this difference attributed to an inadequate amino acid profile of these ingredients. Bureau et al. (2000) also suggested that growth rates of rainbow trout were inversely proportional to the dietary level of feather meal when it replaced fish meal, by virtue of feather meal's limited lysine content. Finally, when Pfeffer et al. (1994) supplemented diets for rainbow trout containing hydrolysed feather meal with lysine both energy and protein retention were considerably improved. In the present trial however, the small but significant difference in weight gain between salmon given the FTH and CON diets was not attributable to dietary amino acids. All diets were found to have very similar digestible amino acid profiles (C. G. Carter et al., unpublished results), which exceeded the requirements calculated for salmonids (NRC, 1993). A reduction in the carcass ash content of salmon on FTH suggested poor bone mineralization. In salmonids this has been attributed to dietary deficiencies of phosphorus, also a causative agent of growth retardation (Lall, 1991). However, literature values show that typical phosphorus concentrations and their digestibility coefficients in salmonids are higher in poultry feather meal (Sugiura et al., 1998) than in lupin meal (Petterson et al., 1997; Burel et al., 1998). Subsequently, the exact reason for the slight reduction in growth of FTH-fed salmon relative to the control remains unknown, and warrants further investigation. Interestingly, reducing the poultry feather meal to $200 \mathrm{~g} / \mathrm{kg}$ of the protein, and including lupin meal overcame the mechanisms responsible for this lower weight gain.

Lupin meal was shown to be a good protein source for partial replacement of fish meal. Under similar experimental conditions, previous research has shown that growth performance in Atlantic salmon was not affected when proportionately 0.33 (Carter and Hauler, 2000) or 0.40 (Carter and Hauler, 1998) of the fish-meal protein was replaced with lupin meal. Similarly, De la Higuera et al. (1988) demonstrated that rainbow trout could be supplied a diet containing up to $300 \mathrm{~g} / \mathrm{kg}$ of lupin meal without causing reduced growth compared with a fish-meal based control. The potential to include lupin meal beyond $400 \mathrm{~g} / \mathrm{kg}$ of the protein in Atlantic salmon diets however is probably limited by the high levels of carbohydrate in this ingredient, which would ultimately result in a decreased digestible energy content and therefore growth (Morales et al., 1994).

\section{Immune function, blood chemistry and disease resistance} Immune parameters measured in the present trial are important components of a fish's defence system. Antiproteases are critical in inactivating extracellular proteases from invading pathogens, whilst lysozyme and neutrophil oxygen radical production are active parasiticidal agents (Secombes, 1994). The production of immunoglobulin too, has a critical rôle in forming complexes with pathogens to bring about opsonization or cellular lysis (Alexander and Ingram, 1992). Whilst these parameters have been previously shown to be modulated by dietary change in various teleosts (e.g. Blazer, 1992; Waagbø et al., 1993; Rumsey et al., 1994; Thompson et al., 1996), in the present trial no modification relative to the control diet occurred. Thompson et al. (1996) however, 
proposed that measuring defence mechanisms prior to challenge only represents resting levels. Measuring immune function shortly after challenge may highlight dietary modifications that were not evident until stimulation (via challenge) of the immune system had occurred. This is further highlighted by mammalian research which has demonstrated that nutrients are preferentially directed towards the immune system, rather than growth, during times of infection (Beisel, 1977). This includes the distribution of amino acids towards the liver for synthesis of acute phase proteins such as antiprotease (Wannemacher, 1977) and suggests suboptimal nutrient intake prior to infection may result in a diminished immune response. It seems a logical step therefore to evaluate immune function after the dietary protein source (and subsequently the amino acid profile) has been altered. Whilst studies on the use of soya-bean meal (because of its antigenic properties) in diets for salmonids and its subsequent effects on immune function have been widely undertaken (e.g. Neji et al., 1993; Rumsey et al., 1994 and 1995; Krogdahl et al., 2000), few have investigated other proteins. Notably, Steffens (1994) examined some basic haematological parameters in rainbow trout given practical diets with proportionately 0.50 or 1.00 (plus additional lysine, or lysine and methionine) of the fish meal replaced by a combined poultry by-product and poultry feather meals. Similarly to the present trial, none of the measured parameters (haematocrit, haemoglobin and erythrocyte numbers) was adversely affected. To our knowledge, the affect lupin meal may have on immune function has not previously been examined.

Challenge with $V$. anguillarum in the present trial failed to result in mortality rates greater than $22 \%$. Unfortunately these low rates of mortality suggest the concentration of bacteria administered to the salmon was probably not sufficient enough to clearly demonstrate inadequacies (if any) in the diets. Nevertheless, data presented suggest the alternative protein sources tested were not detrimental to disease resistance.

In conclusion, the supply of marine products such as fish meal is not a finite resource, and the aquaculture industry must be vigilant in identifying alternative protein sources to fish meal. Whilst growth and efficiencies of aquatic species given novel protein sources will most probably determine their use in aquafeeds, the affect it may have on immune function must not be overlooked. The present study is one of very few to investigate both growth and immune parameters, and we have successfully shown that dehulled lupin in particular is an excellent source of protein for Atlantic salmon, stimulating growth and immune function as well as controls given fish meal.

\section{Acknowledgements}

The authors wish to thank Dr J. Carson from DPIWE, Tasmania, for the $V$. anguillarum strain and technical expertise, and the technical assistance of B. Verbeeten, R. Morrison and M. Foale. The provision of ingredients from Pivot Aquaculture, Peerless Holdings and Milne Feeds is gratefully appreciated. This work was funded by the Cooperative Research Centre for Aquaculture and the Fisheries Research and Development Corporation.

\section{References}

Alexander, J. B. and Ingram, G. A. 1992. Noncellular nonspecific defence mechanisms of fish. Annual Review of Fish Diseases 2: 249-279.

Anderson, D. P. and Siwicki, A. K. 1996. Assaying nonspecific defense mechanisms in fish: monitoring health, immunosuppression, immunostimulation and immunization regimes. In Fish vaccinology (ed. R. Gudding, A. Lillehaug, P. J. Midtlyng and F. Brown), pp. 1-26. Karger, Basel.

Anderson, J. S., Lall, S. P., Anderson, D. M. and Chandrasoma, J. 1992. Apparent and true availability of amino acids from common feed ingredients for Atlantic salmon (Salmo salar) reared in sea water. Aquaculture 108: 111-124.

Association of Official Analytical Chemists. 1990. Official methods of analysis. AOAC, Inc., Arlington, VA.

Association of Official Analytical Chemists. 1995. Official methods of analysis. AOAC, Inc., Arlington, VA.

Beisel, W. R. 1977. Metabolic and nutritional consequences of infection. In Advances in nutritional research (ed. $\mathrm{H}$. $\mathrm{H}$. Draper), pp. 125-144. Plenum Press, New York.

Blazer, V. S. 1992. Nutrition and disease resistance in fish. Annual Review of Fish Diseases 2: 309-323.

Bligh, E.G. and Dyer, W. G. 1959. A rapid method of total lipid extraction and purification. Canadian Journal of Biochemistry and Physiology 37: 911-917.

Bureau, D. P., Harris, A. M., Bevan, D. J., Simmons, L. A., Azevedo, P. A. and Cho, C. Y. 2000. Feather meals and meat and bone meals from different origins as protein sources in rainbow trout (Oncorhynchus mykiss) diets. Aquaculture 181: 281-291.

Bureau, D. P., Harris, A. M. and Cho, C. Y. 1999. Apparent digestibility of rendered animal protein ingredients for rainbow trout (Oncorhynchus mykiss). Aquaculture 180: 345-358.

Burel, C., Boujard, T., Corraze, G., Kaushik, S. J., Boeuf, G., Mol, K. A., Vandergeyten, S. and Kuhn, E. R. 1998. Incorporation of high levels of extruded lupin in diets for rainbow trout (Oncorhynchus mykiss): nutritional value and effect on thyroid status. Aquaculture 163: 325-345.

Carter, C. G. and Hauler, R. C. 1998. Evaluation of phytase in Atlantic salmon, Salmo salar L., diets containing fish meal and different plant meals. In Fish meal replacement in aquaculture feeds for Atlantic salmon 93/120 (ed. C. G. Carter), 
pp. 34-45. Fisheries Research and Development Corporation, Deakin.

Carter, C. G. and Hauler, R. C. 2000. Fish meal replacement by plant meals in extruded feeds for Atlantic salmon, Salmo salar L. Aquaculture 185: 299-311.

Carter, C. G., Houlihan, D. F., Buchanan, B. and Mitchell, A. I. 1994. Growth and feed utilization efficiencies of seawater Atlantic salmon Salmo salar L., fed a diet containing supplementary enzymes. Aquaculture and Fisheries Management 25: 37-46.

De la Higuera, M., Garcia-Gallego, M., Sanz, A., Cardenete, G., Suarez, M. D. and Moyano, F. J. 1988. Evaluation of lupin seed meal as an alternative protein source in feeding of rainbow trout (Salmo gairdneri). Aquaculture 71: 37-50.

Ellis, A. E. 1990. Serum antiproteases in fish. In Techniques in fish immunology (ed. J. S. Stolen, T. C. Fletcher, D. P. Anderson, B. S. Roberson and W. B. van Muiswinkel), pp. 95-99. SOS Publications, Fair Haven.

Food and Agriculture Organization. 1997. Aquaculture production statistics. FAO fisheries circular N. 815 rev. 11. FAO, Rome.

Fowler, L. G. 1990. Feather meal as a dietary protein source during parr-smolt transformation in fall chinook salmon. Aquaculture 89: 301-314.

Gnaiger, E. and Bitterlich, G. 1984. Proximate biochemical composition and caloric content calculated from elemental CHN analysis. Oecologia 62: 289-298.

Jarp, J. and Tverdal, A. 1997. Statistical aspects of fish vaccination trials. In Fish vaccinology (ed. R. Gudding, A. Lillehaug, P. J. Midtlyng and F. Brown), pp. 311-320. Karger, Basel.

Krogdahl, Å., Bakke-Mckellep, A. M., Røed, K. H. and Baeverfjord, G. 2000. Feeding Atlantic salmon Salmo salar L. soybean products: effects on disease resistance (furunculosis), and lysozyme and $\operatorname{IgM}$ levels in the intestinal mucosa. Aquaculture Nutrition 6: 77-84.

Lall, S. P. 1991. The minerals. In Fish nutrition (ed. J. E. Halver), pp. 219-257. Academic Press Inc., San Diego.

Lowry, O. H., Rosebrough, N. J., Farr, A. L. and Randall, R. J. 1951. Protein measurement with the folin phenol reagent. Journal of Biological Chemistry 193: 265-275.

Morales, A. E., Cardenete, G., De la Higuera, M. and Sanz, A. 1994. Effects of dietary protein source on growth, feed conversion and energy utilization in rainbow trout, Oncorhynchus mykiss. Aquaculture 124: 117-126.

National Research Council. 1993. Nutrient requirements of fish. National Academic Press, Washington, DC.

Neji, H., Naimi, N., Lallier, R. and De-la-Noue, J. 1993. Relationships between feeding, hypoxia, digestibility and experimentally induced furunculosis in rainbow trout. In Fish nutrition in practice (ed. S. J. Kaushik and P. Luquet), pp. 187-197. Institut National de la Recherche Agronomique, Paris.

Olli, J. J., Krogdahl, Å. and Våbeno, A. 1995. Dehulled solvent-extracted soybean meal as a protein source in diets for Atlantic salmon, Salmo salar L. Aquaculture Research 26: 167-174.
Perera, W. M. K., Carter, C. G. and Houlihan, D. F. 1995. Feed consumption, growth and growth efficiency of rainbow trout (Oncorhynchus mykiss (Walbaum)) fed on diets containing a bacterial single-cell protein. British Journal of Nutrition 73: 591-603.

Peto, R., Pike, M. C., Armitage, P., Breslow, N. E., Cox, D. R., Howard, S. V., Mantel, N., McPherson, K., Peto, J. and Smith, P. G. 1977. Design and analysis of randomized clinical trials requiring prolonged observation of each patient. British Journal of Cancer 35: 1-39.

Petterson, D. S., Sipsas, S. and Mackintosh, J. B. 1997. The chemical composition and nutritive value of Australian pulses. Grains Research and Development Corporation, Canberra.

Pfeffer, E., Wiesmann, D. and Henrichfreise, B. 1994. Hydrolyzed feather meal as feed component in diets for rainbow trout (Oncorhynchus mykiss) and effects of dietary protein/energy ratio on the efficiency of utilization of digestible energy and protein. Archives of Animal Nutrition 46: 111-119.

Pike, I. H., Andorsdottir, G. and Mundheim, H. 1990. The role of fish meal in diets for salmonids, no. 24. International Association of Fish Meal Manufacturers, Hertfordshire.

Refstie, S., Storebakken, T. and Roem, A. J. 1998. Feed consumption and conversion in Atlantic salmon (Salmo salar) fed diets with fish meal, extracted soybean meal or soybean meal with reduced content of oligosaccharides, trypsin inhibitors, lectins and soya antigens. Aquaculture 162: 301-312.

Roberts, R. J. and Shepherd, C. J. 1997. Handbook of trout and salmon diseases. Fishing News Books, Oxford.

Rumsey, G. L., Endres, J. G., Bowser, P. R., Earnest-Koons, K. A., Anderson, D. P. and Siwicki, A. K. 1995. Soy protein in diets of rainbow trout: effects on growth, protein absorption, gastrointestinal histology, and nonspecific serologic and immune response. In Nutrition and utilization technology in aquaculture (ed. C. Lim and D. J. Sessa), pp. 166-188. AOCS Press, Champaign.

Rumsey, G. L., Hughes, S. G. and Winfree, R. A. 1993. Chemical and nutritional evaluation of soya protein preparations as primary nitrogen sources for rainbow trout (Oncorhynchus mykiss). Animal Feed Science and Technology 40: 135-151.

Rumsey, G. L., Siwicki, A. K., Anderson, D. P. and Bowser, P. R. 1994. Effect of soybean protein on serological response, non-specific defense mechanisms, growth and protein utilization in rainbow trout. Veterinary Immunology and Immunopathology 41: 323-339.

Secombes, C. J. 1994. Enhancement of fish phagocyte activity. Fish and Shellfish Immunology 4: 421-436.

Siwicki, A. K., Anderson, D. P. and Rumsey, G. L. 1994. Dietary intake of immunostimulants by rainbow trout affect non-specific immunity and protection against furunculosis. Veterinary Immunology and Immunopathology 41: 125-139.

Steffens, W. 1994. Replacing fish meal with poultry byproduct meal in diets for rainbow trout, Oncorhynchus mykiss. Aquaculture 124: 27-34.

Sugiura, S. H., Dong, F. M., Rathbone, C. K. and Hardy, R. W. 1998. Apparent protein digestibility and mineral availabilities in various feed ingredients for salmonid feeds. Aquaculture 159: 177-202. 
Thompson, I., Fletcher, T. C., Houlihan, D. F. and Secombes, C. J. 1994. The effect of dietary vitamin A on the immunocompetence of Atlantic salmon (Salmo salar L.). Fish Physiology and Biochemistry 12: 513-523.

Thompson, K. D., Tatner, M. F. and Henderson, R. J. 1996. Effects of dietary (n-3) and (n-6) polyunsaturated fatty acid ratio on the immune response of Atlantic salmon, Salmo salar L. Aquaculture Nutrition 2: 21-31.

Waagbø, R. 1994. The impact of nutritional factors on the immune system in Atlantic salmon, Salmo salar L. : a review. Aquaculture and Fisheries Management 25: 175-197.

Waagbø, R., Glette, J., Raa Nilsen, E. and Sandnes, K. 1993. Dietary vitamin C, immunity and disease resistance in
Atlantic salmon (Salmo salar L.). Fish Physiology and Biochemistry 12: 61-73.

Wannemacher, R. W. 1977. Key role of various individual amino acids in host response to infection. Journal of Clinical Nutrition 30: 1269-1280.

Wedemeyer, G. A. 1996. Physiology of fish in intensive culture systems. Chapman and Hall, New York.

Wedemeyer, G. A. and Ross, A. J. 1973. Nutritional factors in the biochemical pathology of corynebacterial kidney disease in the coho salmon (Oncorhynchus kisutch). Journal of the Fisheries Research Board of Canada 30: 296-298.

(Received 11 October 2000-Accepted 31 January 2001) 